\title{
DIPTERA FROM NEPAL
}

\section{THE BLOW FLIES (DIPTERA: CALLIPHORIDAE)}

By MAURICE T. JAMES

SYNOPSIS

This paper is based on a collection of Calliphoridae made by R. L. Coe on the British Museum East Nepal Expedition of I96I-I962. Fourteen species are listed, of which three are described as new.

All holotypes and allotypes are in the British Museum (Natural History). I express my gratitude to Mr. Coe and to the officials of the Museum for making this interesting collection available to me for study.

\section{Subfamily POLLENIINAE \\ Pollenia rudis (Fabricius)}

Musca rudis Fabricius, I794:314.

E. Nepal : Taplejung Distr., above Sangu, damp evergreen oak forest, c. 9,200', I ㅇ, 2-26.xi.Ig6r (R. L. Coe).

This common and widespread Holarctic species has been recorded from India by Senior-White, Aubertin and Smart (I940).

\section{Subfamily GALLIPHORINAE}

\section{Calliphora vomitoria (Linnaeus)}

Musca vomitoria Linnaeus, I785 : 595.

E. Nepal : Taplejung Distr., above Sangu, damp evergreen oak forest, c. I0,400', I + , 2-26.xi.I96I (R. L.Coe) ; Sangu, mixed vegetation by stream in gully, c. 6,200', I ô, xi.I96I-i.Ig62 (R. L.Coe).

Like the above, this is a common and widespread Holarctic species. Senior-White, Aubertin and Smart have recorded it from the western Himalayas, Darjeeling, and Sikkim. 


\section{Lucilia porphyrina (Walker)}

Musca porphyrina Walker, I856: 24.

E. Nepal : Taplejung Distr., Sangu, mixed vegetation by stream in gully, c. $6,200^{\prime}$, I 오 I $\widehat{o}$, x.I96I-i.Ig62 (R. L. Coe) ; below Sangu, by stream in shady ravine, c. 6,000', I ઈ, 30.x.I96I (R.L.Coe) ; above Sangu, old mixed forest, c. 6,200', 2 ㅇ, 25-28.x.Ig6r (R. L. Coe).

This is a widespread Oriental, eastern Palearctic, and Australian species.

\section{Lucilia papuensis Macquart}

Lucilia papuensis Macquart, I842 : I4I.

E. Nepal : Taplejung Distr., above Sangu, evergreen shrub, c. 6,500', I ${ }^{\prime}$, 5-I3.X.I96I (R. L. Coe) ; between Sangu and Tamrang, mixed shrubs in deep gorge, c. 5,200, 2 ô, x-xi.Ig6I (R. L. Coe).

This widespread Oriental and Australasian species is, according to Senior-White, Aubertin and Smart (I940), one of the commonest Indian green-bottle flies. It is similar in appearance to $L$. porphyrina but may readily be differentiated from that species by the position of the first pair of postsutural acrostichals, which are in line with the second pair of posterior dorsocentrals (distinctly in front of the posterior dorsocentrals in porphyrina) and by the shorter third antennal segment, the apex of which is distant from the oral margin by at least the width of the third antennal segment (much less so in porphyrina).

\section{Bengalia subnitida sp. n.}

$$
\text { (Text-fig. 39) }
$$

MALE. Head yellow in ground colour, becoming brownish on the frontals and parafrontals ; a shining black spot on each parafacial opposite bases of antennae ; head mostly whitish to yellowish pollinose, pollen of parafrontals brownish yellow. Parafacials, parafrontals, and frontals except upper third and on a narrow median stripe, with rather abundant, short, black setulae ; pile of occiput and genae soft, rather long, whitish ; a few black setulae near vibrissae and along oral margin ; hairs of upper part of occiput scant. Sides of front parallel, about one-third head width. Clypeus rounded, but little projecting, apparent but barely so when the head is viewed dorsally. Antenna mostly yellow; second segment reddish brown; third segment largely dusky beyond arista ; arista brown at base, otherwise blackish. Uppermost frontal bristle reclinate, almost as long as outer vertical ; 7 to 8 frontals ; vibrissa almost level with lower margin of facial sclerotization; about I I bristles along oral margin below vibrissa. Palpus yellow, somewhat spatulate, with black setulae and bristles; proboscis yellowish brown, the colour somewhat deeper above, the usual bristles black. Measurements of head (in micrometer units : $60=\mathrm{I} \mathrm{mm}$.) : head width, 276 ; width, at narrowest, of front, 92 , of frontale, 65 ; length of third antennal segment, 58 ; distance vibrissa to oral margin, 5 ; distance between vibrissae, 50 .

Thorax black; humeral slopes and immediate posthumeral areas of mesonotum reddish yellow to yellowish ; propleuron yellow, becoming dusky in its depression ; apex of scutellum becoming yellowish. Protuberances below wing bases yellow. Mesonotum densely brownish pollinose, marmorated as a result of patches of less dense pollen ; thickly black setulose except a small triangular presutural patch and an elongated wedge-shaped postsutural patch between the dorsocentral and intra-alar rows. Dorsocentrals $2: 4$. Pleura whitish pollinose and mostly 
black setulose; hairs of mesothoracic and metathoracic spiracles whitish; some long bristle-like setae in mesopleural row, mixed black and yellow; pteropleural setae mostly black, some whitish. Postalar declivity with fine whitish pile. Prosternal hairs white. Legs largely yellow, the front femur dorsally and the middle and hind femora except at extreme base and apex black. Bristles of under side of thorax appearing especially long and dense, resulting especially from rows on the ventral surface of the sternopleura and on the middle and hind coxae. All tibiae long-villous posteroventrally, the hind pair also anteroventrally ; apical half of first and second tibiae and apical two-thirds of hind tibia with long hairs, increasing in length from about diameter of tibia on the first to twice diameter of tibia on the third pair. Front tibia with a closely-set row of short spinose bristles on its second fourth ventrally ; hind femur with a posteroventral apical comb of about ten spines ; hind tibia without posterodorsals ; hind tibia and basitarsus each with a dense ventral brush of black setulose hairs. Anteroventral surface of front basitarsus, apical half of front tibia, and posteroventral surface of first two tarsomeres of hind tarsus with dense golden velvety pile; vestiture of legs otherwise black. Wings uniformly dusky hyaline ; epaulet and basicostal scale yellow ; veins yellowish toward wing base, becoming dusky apically. Squamae dusky. Halteres yellow.

Abdomen mostly black. Apparent first tergum yellowish in an indefinitely delimited triangle below the scutellum ; first and second sterna except apex of latter yellow. Sides and ventral surface of apparent first tergum, first sternum, and median area of second sternum whitish pollinose ; pollen of rest of abdomen concolorous with background, the abdomen consequently subshining black dorsally and with somewhat the appearance of being " greased ". Vestiture consisting of abundant short black setulae and of longer hairs ventrally, those on the basal sterna being yellowish to whitish with a few blackish intermixed. Hypopygium more shining than rest of abdomen. Apical plate shallowly and broadly notched medially (Text-fig. 39). Length, I3 $\mathrm{mm}$.

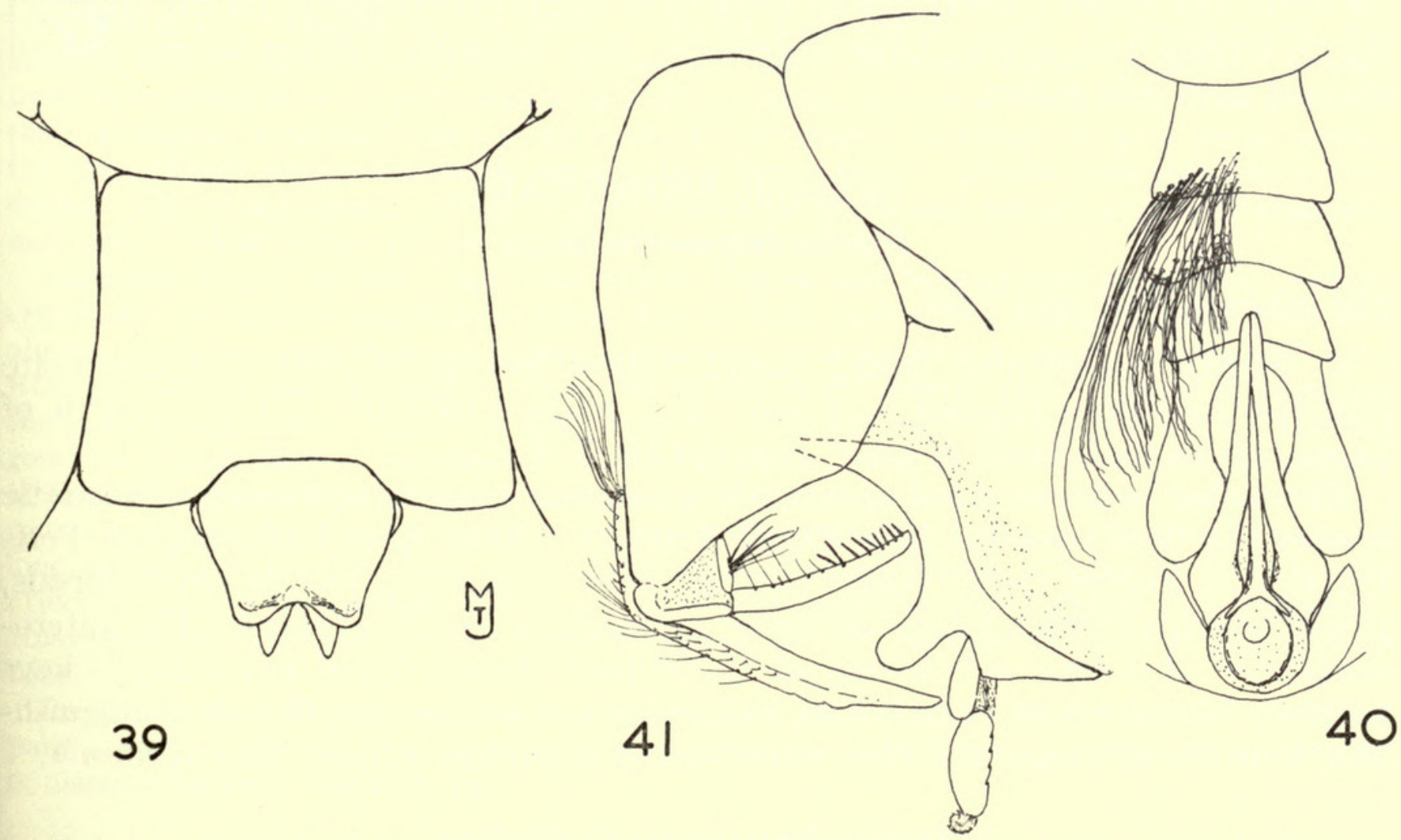

Figs. 39-4I. 39. Bengalia subnitida, sp. n. Apical plate and preceding sternite of male. (Bristles and setae omitted.) 4o. Metallea setiventris, sp. n. Genitalia and third to sixth sternites of male, ventral view. (Setae and bristles omitted except on right half of third and fourth sternites.) 4I. Isomyia coei, sp. n. $\hat{o}$ genitalia spread, lateral view. (Bristles and setae of hypopygium omitted.) 
FEMALE. Front broader at antennal bases, a little tapering toward vertex ; maximum width, 95 micrometer units, compared with 255 for head width. Bristles on coxae and ventral surface of sternopleuron dense, as in the male, but not nearly so long. Hind femur black only dorsally. Tibiae not villous ; front tibia and hind femur without rows of spines or spinous bristles as described for the male. Ventral brush of hind tibia and basitarsus greatly reduced. Abdominal sterna and genital segments yellow ; hairs of sterna much shorter than in male, yellowish on sternum I, on 2 except apex, and on the median third of the remaining sterna (where they might easily be overlooked) ; otherwise black and black-setulose. Sterna 2 to 4 each with a pair of erect black bristles. Otherwise except sexually as described for the male.

Holotype ô. E. Nepal : Taplejung Distr., below Sangu, by stream in shady ravine, c. 6,000', 30.x.I96I (R. L. Coe), B.M. (Nat. Hist.).

Allotype ․ Same data as holotype.

The shining black abdomen separates this from other Oriental species known to me. The relationship seems closest to B. varicolor (Fabricius), but that species has discal macrochaetae on the apparent fourth tergum, the abdomen is pollinose, and the apical plate of the male is deeply notched. In Senior-White, Aubertin and Smart's key to the Oriental species it traces to couplet I2, but both species in that couplet (escheri Bezzi and xanthopyga Senior-White) have pale-pollinose, partly pale-coloured abdomens, different tibial armatures, only short-haired hind tibiae, mostly pale legs, and other points of variance. Séguy (I946) has described three Oriental species (chromatella, pallidicoxa, and unicolor) subsequent to Senior-White, Aubertin and Smart's work, but all these have discal macrochaetae on the apparent fourth tergum and, among other differences, the abdomen is either largely pale or covered with pale pollen.

\section{Subfamily RHINIINAE \\ Idiella tripartita (Bigot)}

Idia tripartita Bigot, I874: 236.

E. Nepal : Taplejung Distr., Sangu, yellow blooms of cultivated composite (Guizotia abyssinica Cassini), c. 6,200', I ô, I6-29.X.I96I (R. L. Coe) ; north of Sangu, above river bank, c. 5,000', 5.i.I962 (R. L. Coe).

This rather widespread but apparently uncommon Oriental and eastern Palearctic species has been recorded from China (Fukien), Sikkim, and Darjeeling by Peris (I952). As Zumpt (I956) points out, the hind tibia has a row of anterodorsals, two of which are much longer and more conspicuous than the others. The anterodorsal row, if it were well developed, would lead through Peris' and Zumpt's keys to genus Rhinia, rather than Idiella, but in this species this row, though distinguishable from the setulae of the tibia, is feeble and much less distinct than in Rhinia.

\section{Stomorhina procula (Walker)}

Idia procula Walker, I849: 808 .

E. Nepal: Taplejung Distr., Sangu, mixed vegetation by stream in gully, c. $6,200^{\prime}, 2$ + , ix-X.I96I, and I $\sigma^{\prime}$, xi.I96I-i.Ig62 (R. L. Coe) ; Sangu, yellow blooms 
of cultivated composite (Guizotia abyssinica Cassini), c. 6,200', I ô, I0-I6.xii.Ig6I (R. L. Coe ) ; Sangu, blooms of wild cherry, c. 6,200', I ô, I5-I8.xi.Ig6I (R. L. Coe).

\title{
Metallea setiventris $\mathrm{sp} . \mathrm{n}$.
}

\author{
(Text-fig. 40)
}

MALE. Head mostly yellow ; parafrontals with somewhat of a brownish tinge ; parafrontals and parafacials thickly yellow pollinose ; centre of face, especially underlying antennae, whitish pollinose ; oral margin, vibrissal area, and anterior half of gena almost devoid of pollen ; occipital orbits, centre of occiput, and posterior half of gena densely whitish pollinose. Occiput mostly black, ocellar triangle blackish. Antennal bases but narrowly separated from each other, with only vestiges of a carina between them. Eyes subcontiguous, frontale completely obscured for a considerable distance. Antenna yellow, the third segment blackish externally, arista blackish ; arista pubescent half way or more, the longest hairs distinctly longer than maximum diameter of arista. Proboscis blackish ; palpi yellow, whitish pollinose only apically. Frontals 5 or 6 ; outer verticals not developed; 2 or 3 black setulae immediately above and a row along oral margin below vibrissa ; parafrontal with several fine yellow hairs visible only on close examination under high magnification ; a few minute black setulae along frontal row ; postoccipital row black, other occipital and genal hairs yellow.

Thorax metallic green, mesonotum and parts of pleura strongly coppery in certain lights, scutellum with but traces of a coppery sheen ; mesonotum quite distinctly whitish pollinose, the setulae and bristles arising from small bare black spots. Bristles black; setulae of mesonotum, scutellum, humerus except below, extreme anterodorsal corner of mesopleuron, and anterior face of sternopleuron black, setulae and hairs otherwise whitish to yellow. Femora black with greenish to coppery reflections ; tibiae yellow, becoming blackish to black on apical third to fourth, especially below ; all basitarsi and second tarsomere of hind tarsus yellow, the apex of each segment blackish, remainder of tarsus black. Middle tibia with one anterodorsal. Pile of legs black. Wing hyaline, somewhat infuscated toward costa and especially near apex ; veins yellow at base, otherwise brownish.

Abdomen largely yellow ; apparent fourth tergum and hypopygium green with coppery reflections ; a median longitudinal black spot on each of first four apparent terga, each spot almost connected with those on adjacent segments so as to form a narrow longitudinal band from the base of the abdomen to about the middle of the fourth tergum (where it interrupts the green background). First four sterna yellow ; fifth and sixth (pre-genital) black ; external genitalia mainly black. Setulae and pile mostly black ; first two sterna and ventral surfaces of first three apparent terga wholly with fine yellowish hairs ; apex of second sternum with a row of 5 or 6 slender black bristles ; third and fourth sterna on their apical half with numerous long setulae and bristles, those on the sides, especially on sternum 3, being particularly long (Text-fig. 40). Fifth sternum subshining ; lobes of pregenital sternite rugulose, with moderately abundant black hairs and setulae ; outer forceps more finely rugulose, glabrous at their bulbous base.

Length, $5 \mathrm{~mm}$. Measurements in micrometer units $(6 \mathrm{O}=\mathrm{I} \mathrm{mm}$.) : head width, $6 \mathrm{I}$; width of parafacial, 7 , of frontale, $\mathrm{I} \cdot 5$; distance vibrissa to nearest part of eye, $\mathrm{I} 3$, vibrissa to oral margin 6 , distance between vibrissae, I5.

Holotype ô. E. Nepal : Taplejung Distr., Dobhan, cut rice steppes above River Maewa, 4,000', 28.i.62 (R. L. Coe), B.M. (Nat. Hist.).

This small fly superficially resembles Rhynchomyia setipyga Villeneuve, but upon closer inspection it is different in many respects. The pilose propleuron places it in 
Metallea, according to Peris' interpretation of this genus ; in Senior-White, Aubertin \& Smart's key it runs to Metalliopsis, which Peris considers a synonym of Metallea, but those authors, as shown by Peris, have confused three species which they cite in synonymy. In Peris' key to Metallea this species traces to setosa Townsend on the basis of its distinctly pubescent arista and the presence of only one anterodorsal on the middle tibia. However, setosa is a distinctly larger species, with a different coloration (notably a more distinctly green mesonotum and black parafacials with a polished spot on the lower part of each) ; also, in setosa the remarkable setation of the sternites is lacking.

\section{Metallea setosa (Townsend)}

Metalliopsis setosa Townsend, I917 : I98.

E. Nepal: Taplejung Distr., above Sangu, edge of mixed forest, c. 6,500', I ô, I7.X-I.Xi.Ig6I (R.L. Coe) ; Sangu, mixed vegetation by stream in gully, c. $6,200^{\prime}$, I ô, ix-X.I96I (R. L. Coe) ; Sangu, yellow bloom of cultivated composite (Guizotia abyssinica Cassini), c. 6,200', I , I6-29.x.I96I (R. L. Coe).

\section{Rhynchomyia setipyga Villeneuve}

Rhynchomyia setipyga Villeneuve, I929: 185.

E. Nepal : Arun Valley, Tumlingtar, yellow blooms of cultivated composite (Guizotia abyssinica Cassini), plateau, c. 2,000', Io ô, I ㅇ, 8-25.xii.Ig6I (R. L. Coe) ; Taplejung Distr., Dobhan, cut rice steppes above River Maewa, c. 4,000', I ô, 28.i.Ig62 (R. L. Coe).

This species was described from Formosa, and Peris (I952) considers that Musca collecta Walker, I860, known only from the badly broken type from Macassar, may be a synonym. $R$. setipyga cannot be a synonym of Metalliopsis setosa Townsend, as so considered by Senior-White, Aubertin \& Smart.

The present series seems to be this species, the only discrepancy that I can find being the lack of the triangular brownish area which Villeneuve describes as occurring below each eye. The arista is short-pubescent, though the pubescence is distinct ; the parafacials and parafrontals have a few fine yellow hairs which are difficult to see because of their texture and similarity in color to the background; the female has a few black frontal setulae. The femora of the male are wholly black except at the extreme apex ; those of the female are black on the apical half. The abdominal pattern is variable, but the abdomen is predominantly yellow, with a black apex (beyond the third apparent segment), which is largely obscured by yellow pollen ; usually a median polished abdominal black band, extending over the apparent second to fourth terga (and interrupting the pollinose area of the latter), together with a transverse band at the apex of the third tergum, give the effect of a cross. The male genitalia are as illustrated by Peris; particularly, the processes of the pregenital sternite are elongated, with a patch of approximately six erect spines near the base of each. 


\section{Isomyia coei sp. n.}

(Text-fig. 4I)

MALE. Head mostly black, face below yellowish, oral margin yellowish to reddish yellow ; covered with pollen, mostly dense (that of the face rather sparse), except on the usual bare area of the upper occiput, which is shining black; pollen in general cinereous below, becoming yellowish on the parafacials and parafrontals. Hairs of parafacials and parafrontals short, inconspicuous, mostly pale, some black on the parafrontals and parafacials below. Genal and occipital pile white. Front at narrowest about width of ocellar triangle ; frontal stripe narrow but distinct throughout. Antennae yellowish to reddish yellow ; apical half of third segment darkened; arista black. Palpus spatulate, yellow, with black setulae. Proboscis black.

Thorax metallic green, with bronze reflections especially along the acrostichal, dorsocentral and intra-alar areas, on the disc of the scutellum, and on the middle of the mesopleuron and sternopleuron. Scutellum about $\mathrm{I} \cdot 3$ as broad as long. Mesonotum and scutellum with short black setulae ; pleura mostly whitish pilose ; some black setulae on upper part of mesopleuron. Spiracles black haired. All bristles black. Dorsocentrals 2:4, acrostichals $2: 2$, mesopleurals 5. Postalar declivity bare. Legs black, tibiae and base of hind basitarsus reddish brown. Middle tibia without a ventral bristle ; front tibia with anterodorsal row developed for about three-fifths length of tibia. Wings subhyaline; stem vein with 3 to 6 long setulae above, bare below ; $r-m$ opposite end of $S c_{1}$; bend of $M_{1+2}$ broadly rounded, the apical cell narrowly open. Epaulet black; basicostal scale yellow. Squamae white with narrow yellow rims; thoracic squama not lobulate posteriorly and distant from the scutellum.

Abdomen green, with bronze reflections dorsally, mostly densely whitish pollinose and with black setulae and bristles. Some whitish hairs on first sternum and apparent first three terga ventrally toward the sterna. Lobes of pregenital sternite rounded apically. Anterior claspers slender, but slightly bowed apically; paralobes slender, parallel-sided, rounded apically, with erect setulae ventrally (Text-fig. 4I). Length, 7-8 $\mathrm{mm}$.

Measurements of holotype in micrometer units $(60=\mathrm{I} \mathrm{mm}$.$) : head width, \mathrm{I} 45$; width of vertex, 24, of front (minimum), 4, of frontal stripe (minimum), 2, of parafacial opposite antenna, I8, of parafacial opposite vibrissa, I 5 ; distance between vibrissae, 28 ; length of third antennal segment, 20.

FEMALE. Gena black as in male, or sometimes more or less reddish yellow anteriorly. Front tapering from vertex to opposite lunule, then broadening rapidly. Frontal stripe reddish brown, on an average about one-third width of front, almost parallel-sided and consequently occupying a greater percentage of the front above and a smaller percentage below. Acrostichals usually I : 2. Otherwise except sexually as described for the male. Measurements in micrometer units : head width, I 70 ; width of vertex, 42 , of front half way between anterior ocellus and lunule, 55, of parafacial opposite antennae, 25, of parafacial opposite vibrissa, I 7 .

Holotype ô. E. Nepal: Arun Valley, Tumlingtar, plateau, c. 2,000', yellow blooms of cultivated composite (Guizotia abyssinica Cassini), I6-29.xii.I96r (R. L. Coe), B.M. (Nat. Hist.).

Allotype ㅇ. Same data, except Io-I6.xii.I96r.

Paratypes, I 9 , same data as holotype ; I $\hat{0}, 3$ 옹 same data as allotype ; I $\hat{0}$, same data as holotype except 8-25.xii.I96r.

This species belongs to the dubiosa group of Peris (I952) and runs in that author's key to pseudonepalana (Senior-White, Aubertin \& Smart), the only Oriental species which Peris refers unquestionably to that group. The elongated, oval lobes of the pregenital sternite readily differentiate it from pseudonepalana, and the genitalia differ in other respects. 


\section{Isomyia pseudoviridana (Peris)}

Thelychaeta pseudoviridiana Peris, I952 : I8o.

E. Nepal : Taplejung Distr., Sangu, yellow blooms of cultivated composite (Guizotia abyssinica Cassini), c. 6,200', 8 ㅇ, 2 ô, I2-29.X.I96I (R. L. Coe) ; Sangu, mixed vegetation by stream in gully, c. $6,200^{\prime}, 3$ ㅇ, 2 o', xi.I96I-i.Ig62 (R. L. Coe) ; north of Sangu, above river bank, on flowers of shrub, c. 5,000', 2 ㅇ, 2 ô, 5.i.Ig62 (R. L. Coe) ; Dobhan, on minute florets of "tassel-flowered" shrub, c. 3,500', 2 今, 23-31.i.Ig62 (R. L. Coe).

\section{Isomyia electa (Villeneuve)}

Thelychaeta electa Villeneuve, I927: 217.

E. Nepal : Taplejung Distr., between Sangu and Tamrang, mixed shrubs in deep gorge, c. 5,200', I ô, x-xi.rg6I (R. L. Coe) ; Sangu, yellow blooms of cultivated composite (Guizotia abyssinica Cassini), c. 6,200', 2 +, I6-29.X.I96I (R. L. Coe).

\section{Strongyloneura (? prolata (Walker))}

Idia (Rhyncomyia) prolata Walker, I860 : I33.

E. Nepal : Taplejung Distr., between Sangu and Tamrang, mixed shrubs in deep gorge, c. $5,200^{\prime}$, I + , x-xi.I96I (R. L. Coe) ; Sangu, mixed vegetation in stream by gully, c. $6,200^{\prime}$, I + , ix-x.Ig6I (R. L. Coe).

Reference of the above specimens to prolata is made with some question because of the lack of males. Only one other species of the genus is recognized as valid by Peris, namely S. prasina Bigot, the type species, from Formosa and Japan. Peris' criterion for the separation of the species, whether the polished black genal spot reaches the eye (prolata) or not (prasina), would place these specimens in the latter species, though I am inclined to believe, on the basis of abdominal coloration and known geographical distribution, that they belong in the former.

\section{REFERENCES}

Bigot, J. M. I874. Diptères nouveaux ou peu connus. Ann. Soc. ent. Fr. (5) 4:235-242.

Fabricius, J. C. I794. Ent. Syst. $4:$ 3I 4.

Linnaeus, C. I758. Syst. Nat. ed. 10:824+iii pp.

Macouart, M. J. I842. Dipt. exot. $2: 460$ pp.

Peris, S. V. I952. La subfamilia Rhiniinae (Dipt., Calliphoridae). An. Estac. exp. Aula Dei (I) $3:$ I-224.

SÉGUY, E. I946. Calliphorides d'extreme orient. Encycl. ent. 10:8I-90, I fig.

Senior-White, R., Aubertin, D. \& Smart, J. I940. The Fauna of British India. Diptera. VI. Calliphoridae. xiii +288 pp. I52 figs. I map. London.

Townsend, C. H. T. I9I7. Indian flies of the subfamily Rhiniinae. Rec. Indian Mus. 13 I $85^{-202 .}$ 
Villeneuve, J. I927. Tachinides nouveaux de Formose et du Congo. Rev. zool. Afr. 15 :

217-224.

WALKER, F. I849. List of the specimens of Dipterous insects in the collection of the British Museum, London 4 : 689-I, I72.

I 856. Catalogue of the Dipterous insects collected at Singapore and Malacca by Mr. A. R. Wallace, with descriptions of new species. J. Linn. Soc. Lond. (Zool.) 1 : 4-39.

I86o. Catalogue of the Dipterous Insects collected at Makessar in Celebes with descriptions of new species. J. Linn. Soc. Lond. (Zool.) 4 : 90-172.

Zumpt, F. 1956. Calliphorinae, In Linder, E. Die Fliegen der Palaearktischen Region. Fasc. I8, no. 64 i. I 40 pp., Io plates, 47 text-figs.

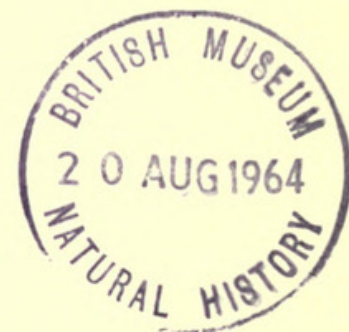




\section{$2 \mathrm{BHL}$ Biodiversity Heritage Library}

James, Maurice T. 1964. "Diptera from Nepal. The blow-flies (Diptera:

Calliphoridae)." Bulletin of the British Museum (Natural History) Entomology 15, 171-179. https://doi.org/10.5962/bhl.part.20539.

View This Item Online: https://www.biodiversitylibrary.org/item/19371

DOI: https://doi.org/10.5962/bhl.part.20539

Permalink: https://www.biodiversitylibrary.org/partpdf/20539

\section{Holding Institution}

Natural History Museum Library, London

\section{Sponsored by}

Natural History Museum Library, London

\section{Copyright \& Reuse}

Copyright Status: In copyright. Digitized with the permission of the rights holder.

Rights Holder: The Trustees of the Natural History Museum, London

License: http://creativecommons.org/licenses/by-nc-sa/4.0/

Rights: http://biodiversitylibrary.org/permissions

This document was created from content at the Biodiversity Heritage Library, the world's largest open access digital library for biodiversity literature and archives. Visit BHL at https://www.biodiversitylibrary.org. 